\title{
Genetic control of lipoprotein(a) concentrations is different in Africans and Caucasians
}

\author{
M ichael Scholz ${ }^{1}, \mathrm{H}$ ans-G eorg $\mathrm{Kraft}^{2}$, A rnulf L ingenhel ${ }^{2}$, R hena Delport ${ }^{3}$, \\ E sté $\mathrm{H}$ Vorster ${ }^{4}$, Heike B ickeböller ${ }^{1}$ and G erd U termann ${ }^{2}$ \\ ${ }^{1}$ Institut für M edizinische Statistik und E pidemiologie, TU, M ünchen, G ermany \\ ${ }^{2}$ Institute for M edical Biology and $\mathrm{H}$ uman Genetics, University of Innsbruck, A ustria \\ ${ }^{3} \mathrm{D}$ epartment of Chemical Pathology, Faculty of M edicine, U niversity of Pretoria \\ ${ }^{4} \mathrm{D}$ epartment of N utrition and Family E cology, U niversity of Potchefstroom, South A frica
}

\begin{abstract}
Lipoprotein(a) (Lp(a)) represents a quantitative trait in human plasma associated with atherothrombotic disease. $L$ arge variation in the distribution of $L p(a)$ concentrations exists across populations which is at present unexplained. Sib-pair linkage analysis has suggested that the apo(a) gene on chromosome $6 q 27$ is the major determinant of $L p(a)$ levels in Caucasians. We have here dissected the genetic architecture of the $L p(a)$ trait in $A$ fricans ( $K$ hoi San, South A frican B lacks) and Caucasians (A ustrians) by family/sib-pair analysis. H eritability estimates ranged from $h^{2}=51 \%$ in B lacks, $h^{2}=61 \%$ in $\mathrm{K}$ hoi San, to $\mathrm{h}^{2}=71 \%$ in Caucasians. A nalysis by a variance components model also demonstrated that the proportion of the total phenotypic variance explained by genetic factors is smaller in A fricans (65\%) than in Caucasians $(74 \%)$. Importantly the sib-pair analysis clearly identified the apo(a) gene as the major locus in Caucasians which explained the total genetic variance. In the A frican samples the apo(a) gene accounted for only half the genetic variance. Together with previous results from population studies our data indicate that genetic control of $L p(a)$ levels seems to be distinctly different between $A$ fricans and C aucasians. In the former genetic factors distinct from the apo(a) locus and also non-genetic factors may play a major role.
\end{abstract}

Keywords: lipoprotein(a); apolipoprotein(a); family analysis; sibpair analysis; heritability; quantitative genetic trait; Caucasians; A fricans

\section{Introduction}

Lipoprotein(a) (Lp(a)) is an unusual quantitative genetic trait in humans with over 1000 -fold concentration differences among individuals and marked differences across populations. ${ }^{1,2} \mathrm{H}$ igh plasma levels of $\mathrm{L} p(a)$

Correspondence: Professor Dr G Utermann, Institute for Medical Biology and Human Genetics, Schöpfstr. 41, 6020 Innsbruck, Austria. Tel: +435125073451 ; Fax: +43512507 2861; E-mail: gerd.utermann@uibk.ac.at

R eceived 28 A pril 1998; revised 28 September 1998; accepted 6 N ovember 1998 are a major susceptibility factor for atherothrombotic disease (coronary heart disease, stroke) in Caucasians and A sians. ${ }^{3-6}$ Understanding the genetic control of $L p(a)$ levels may therefore have practical implications. Whether $L p(a)$ is also a risk factor in Blacks is at present controversial. ${ }^{7,8}$

$L p(a)$ is a complex assembled from low density lipoprotein (LDL) and the plasminogen-related apolipoprotein(a). Like plasminogen apo(a) contains a $5^{\prime}$ signal sequence, a 3' protease domain and so-called $\mathrm{K}$ ringle domains. ${ }^{9}$ Ten different types of K ringle IV domains are present in apo(a), one of which (type K IV- 
2) exists in variable numbers in individual alleles (K IV variable number of repeats $=K$ IV V NTR). Twin, family and sib-pair analysis in Caucasians have suggested that the large variability in $L p(a)$ plasma concentrations is highly heritable with $\mathrm{h}^{2}$ estimates in the order of 93-99\% ${ }^{10-12}$ and almost entirely determined by the apo(a) locus on chromosome $6 q 27 . .^{13,14}$ Three studies have concluded that this locus explains $>90 \%$ of the phenotypic variability in $L p(a)$ plasma concentration in Caucasians. ${ }^{11,12,15} \mathrm{~A} n$ inverse correlation of $\mathrm{K}$ IV repeat number with $L p(a)$ levels exists in all populations analysed so far. The KIV VNTR alone explains $30-70 \%$ of the variability in $L p(a)$ levels across populations depending on the population and the type of analysis. ${ }^{16-18}$ There are, however, notable differences in the $L p(a)$ plasma concentrations as well as in the relation of the K IV VNTR and other intragenic variation to $L p(a)$ levels across ethnic groups. ${ }^{19} L p(a)$ concentrations are about two to threefold higher in A frican and A merican Blacks than in Caucasians. This is neither explained by differences in KIV VNTR frequencies among populations ${ }^{16,17,20}$ nor by known differences in other polymorphisms and at present remains unexplained. The extent to which $L p(a)$ levels are genetically determined in A fricans is also unknown. Recently a study of A frican A mericans showed that $78 \%$ of the variability is due to polymorphisms at or close to the apo(a) locus ${ }^{21}$ but data on A frican Blacks or other aboriginal A frican populations are still lacking. Several observations might suggest that the control of $L p(a)$ levels in A fricans could be in part different in nature from that in Caucasians. The association of the K IV V NTR with $L p(a)$ levels is considerably weaker in B lacks than in Caucasians or A sians ${ }^{16,18}$ and explains significantly less of the phenotypic variability in $L p(a)$ concentrations. $L p(a)$ concentrations associated with K IV VNTR alleles of identical size are also different between ethnic groups. ${ }^{16} \mathrm{~A}$ pentanucleotide repeat polymorphism at $-1.4 \mathrm{~kb}$ in the 5 region of the apo(a) gene is associated with $L p(a)$ levels in Caucasians but not in $A$ fricans ${ }^{19}$ and a $C / T$ polymorphism at +93 affects $L p(a)$ in $A$ fricans but not in Caucasians. ${ }^{22}$ In the present study we have used a family and sib-pair approach to analyse to what extent $L p(a)$ levels are genetically determined in A fricans (South A frican Blacks and Khoi San) and whether there is any contribution of the apo(a) locus beyond the effect of the K IV VNTR in the A frican populations. We further have reanalysed our previously published Caucasian families $^{12}$ using the same methodology as for the
A fricans in order to see whether or not differences exist among these major human groups.

\section{Materials and Methods}

Subjects

EDTA blood was drawn from apparently healthy family members stemming from three populations (Caucasians from A ustria, Khoi San and Blacks from South A frica). The A ustrian samples ( 51 families, constituting 63 nuclear families, 221 individuals) have been described previously. ${ }^{12}$ The $\mathrm{K}$ hoi San sample consisted of 25 nuclear families with 112 individuals which were collected in an area of the Northern Cape Province, called Schmidtsdrift. ${ }^{23}$ Samples from 67 B lack families including 270 individuals were obtained from the NorthWest Province of South A frica. All the Black families belonged to the Tswana people and lived in a rural environment. $A \mathrm{n}$ aliquot ( $1 \mathrm{ml}$ ) of the $A$ frican specimen was centrifuged to obtain plasma and both, blood and plasma were immediately frozen at $-20^{\circ} \mathrm{C}$. All the samples were shipped on dry ice to Innsbruck for further analysis.

\section{Lp(a) Concentration}

A sandwich type ELISA ${ }^{24}$ was used to determine the L $p(a)$ plasma levels. Care was taken that plasma specimen of members from the same family were all thawed on the same day and analysed on the same ELISA plate.

\section{Apo(a) Genotyping}

The number of K IV repeats in the apo(a) allele were determined using pulsed field gel electrophoresis/Southern blotting exactly as described. ${ }^{12,16}$ The number of TTTTA repeats in the $5^{\prime}$ flanking region (Pentanucleotide repeat polymorphism-PNRP) was determined by a PCR-based technique. ${ }^{19}$ The apo(a) alleles leading to a M et or Thr in K IV type 10 (codon 4168 in the apo(a) CDNA ${ }^{9}$ ) were analysed as published previously. ${ }^{25}$

\section{Statistical Methods}

A llele frequencies of the three polymorphisms in the apo(a) gene were estimated by allele counting in unrelated individuals from the three populations. Where two populations were pooled for the analysis, the allele frequencies were also estimated from the combined sample. The distribution of $L p(a)$ concentration was highly skewed in these data. This is a known phenomenon for $L p(a)$ concentrations. Thus $L p(a)$ levels were natural-log-transformed (In) prior to analysis. A square-root transformation was found not to be justified as indicated by classical regression diagnostics.

Two different strategies were applied to identify the interindividual variability for $L p(a)$ concentrations due to genetic components and due to the apo(a) locus in particular: midparent-offspring regression and a variance components approach. Midparent-offspring regression allowed the estimation of the heritability from the slope coefficient of the linear regression of mean $\ln L p(a)$ of offspring on mean In $L p(a)$ of the parents. ${ }^{26} \mathrm{H}$ ere the natural-log-transformation was necessary to make the regression valid. The heritability $h^{2}$ measured by this approach is the contribution of the overall additive genetic variance to the phenotypic variance. To account for the different sibship sizes in the families offspring 
means were weighted with a factor containing the intra-class correlation coefficient $t^{26}$ The intra-class correlation coefficient $t$ has been calculated by a random effects analysis of variance. $^{27}$ Since families were a random sample from the population it was appropriate to consider the effect of belonging to the same family as a random effect of this population.

To make also use of the available genetic information on the apo(a) K IV VNTR a components of variance approach was additionally applied to the nuclear family data. We used the method described by $\mathrm{Amos}^{28} \mathrm{H}$ ere the model for the kth family is represented by

$$
y_{i k}=\mu+X_{i k} \beta+g_{k}+G_{k}+\varepsilon_{k} \text {, }
$$

where $y_{i k}$ is the observed vector of $\ln L p(a)$ concentrations for the ith individual of family $k, \mu$ is the overall mean, $X_{i k}$ is a vector of additionally observable covariates, $G_{k}$ is a random polygenic and $g_{k}$ the unobservable major gene effect for the kth family. Further we assume $G_{k} \sim\left(0, \sigma_{G}^{2} R_{k}\right)$ and $g_{k} \sim(0$, $\left.\sigma_{a}^{2} \Pi_{k}\right)$. Thus, the variance-covariance matrix conditional on the identity by descent (IBD) sharing of relative pairs is partitioned as

$$
\operatorname{Cov}\left(Y_{i}, Y_{j} \mid \pi_{i j}\right)=\left\{\begin{array}{l}
\sigma_{a}^{2}+\sigma_{G}^{2}+\sigma_{e}^{2} \text { if } i=j \\
\pi_{i j} \sigma_{a}^{2}+R_{i j} \sigma_{G}^{2} \text { if } i \neq j
\end{array}\right.
$$

The expression $\pi_{i j}$ is the estimated proportion of alleles IBD at the marker locus for the $i, j$ th pair, $R_{i j}$ is the kinship coefficient between relative pairs. In general the term $\sigma_{a}^{2}$ represents the additive genetic variance due to a linked major locus, $\sigma_{G}^{2}$ is the variance due to unlinked genetic factors or polygenes and $\sigma_{\mathrm{e}}^{2}$ represents the residual variance. Therefore, $\sigma_{a}^{2}+\sigma_{G}^{2}+\sigma_{e}^{2}$ will be denoted by $\sigma_{\mathrm{p}}^{2}$ and describes the total phenotypic variance. Further we assumed for this analysis that there is no dominance component of genetic variance, no genetic-environment interaction and a recombination fraction of $\theta=0$. These assumptions are reasonable since it has been extensively demonstrated that the apo(a) locus is a candidate gene region for our trait of interest and, as stated, ${ }^{28}$ a dominance component is generally negligible. Consequently $\sigma_{a}^{2}$ represents the genetic variability due to a completely linked major locus, namely the apo(a) gene. Heritabilities were estimated from the ratio of $\sigma_{a}^{2} / \sigma_{\mathrm{p}}^{2}$ (narrow sense) and from the ratio of $\left(\sigma_{a}^{2}+\sigma_{G}^{2}\right) / \sigma_{P}^{2}$ (broad sense), respectively. The latter value of the heritability is comparable to the $h^{2}$ from the midparent-offspring regression.

A quasi-likelihood method was applied to estimate the variance components and with it the heritabilities. In simulation studies ${ }^{29}$ this approach yielded better results than the usual $\mathrm{H}$ aseman-E Iston method ${ }^{30}$ in almost all circumstances, particularly when there was strong non-normality in the error structure, as in our dataset. Therefore the Haseman-EIston method was not considered here. A nother advantage of the employed method was the possibility to incorporate additional covariates (eg age and sex) simultaneously. E stimates for the proportion of alleles IBD were obtained from the SIBPA L program of SAGE. ${ }^{31}$ Simultaneous $95 \%$ confidence intervals for all ratios were calculated according to Fieller's theorem. ${ }^{32}$

\section{Results}

$L p(a)$ plasma levels and apo(a) genotype (number of $\mathrm{K}$ IV repeats in both apo(a) alleles) were determined in all family members from three populations (K hoi San and Blacks from South A frica and Caucasians from A ustria). The distribution of the K-IV alleles in the three populations is shown in Figure 1 (only the parents were considered for this presentation). In the statistical analysis only those families and individuals were included in which the offspring apo(a) K IV VNTR matched the paternal KIV VNTR. In the A frican samples a large proportion of families/individuals had to be excluded due to non-paternity and also nonmaternity. Tswana people have a different comprehension of 'family' compared with Caucasians. In addition to the genetic children the 'family' may include also children of one of the parents by another partner, or who have been adopted. Other apo(a) intragenic markers were used to confirm paternity for the remaining children. Mean age and sex ratio in the three population samples used for the analysis are given separately for parents and children in Table 1.

\section{Midparent-Offspring Analysis}

Heritability of $L p(a)$ Concentrations in Africans For estimating the heritability of $L p(a)$ concentrations by midparent-offspring regression analysis 55 B lack South A frican nuclear families with a total of 105 children, and $22 \mathrm{~K}$ hoi-San nuclear families including 44 children, were available. In all families IBD status at the apo(a) locus was determined by the analysis of the K IV VNTR using PFGE/genomic blotting. Other intragenic polymorphisms (1.4kb PNRP, $\mathrm{K}$ IV-10 $M / T, C / T$ polymorphism in the $5^{1}$ region $^{33}$ ) were also analysed when the $\mathrm{K} I V$ polymorphism alone was not informative (data not shown). L p(a) concentrations were determined in all individuals by ELISA. A basic description of $L p(a)$ levels and their distribution in the families is given in Table 1 . In a first step regression analysis was performed using untransformed $L p(a)$ values (data not shown). Validation of the regression analysis using the residuals demonstrated that the requirements for linear regression are not fulfilled by the untransformed values. Therefore the heritabilities calculated on the basis of untransformed $L p(a)$ values cannot be used. Since the distribution of $L p(a)$ concentrations is skewed in the populations (Table 1) a transformation of $L p(a)$ values to natural log (In) values appeared necessary and appropriate before the further analysis. A fter transformation the 


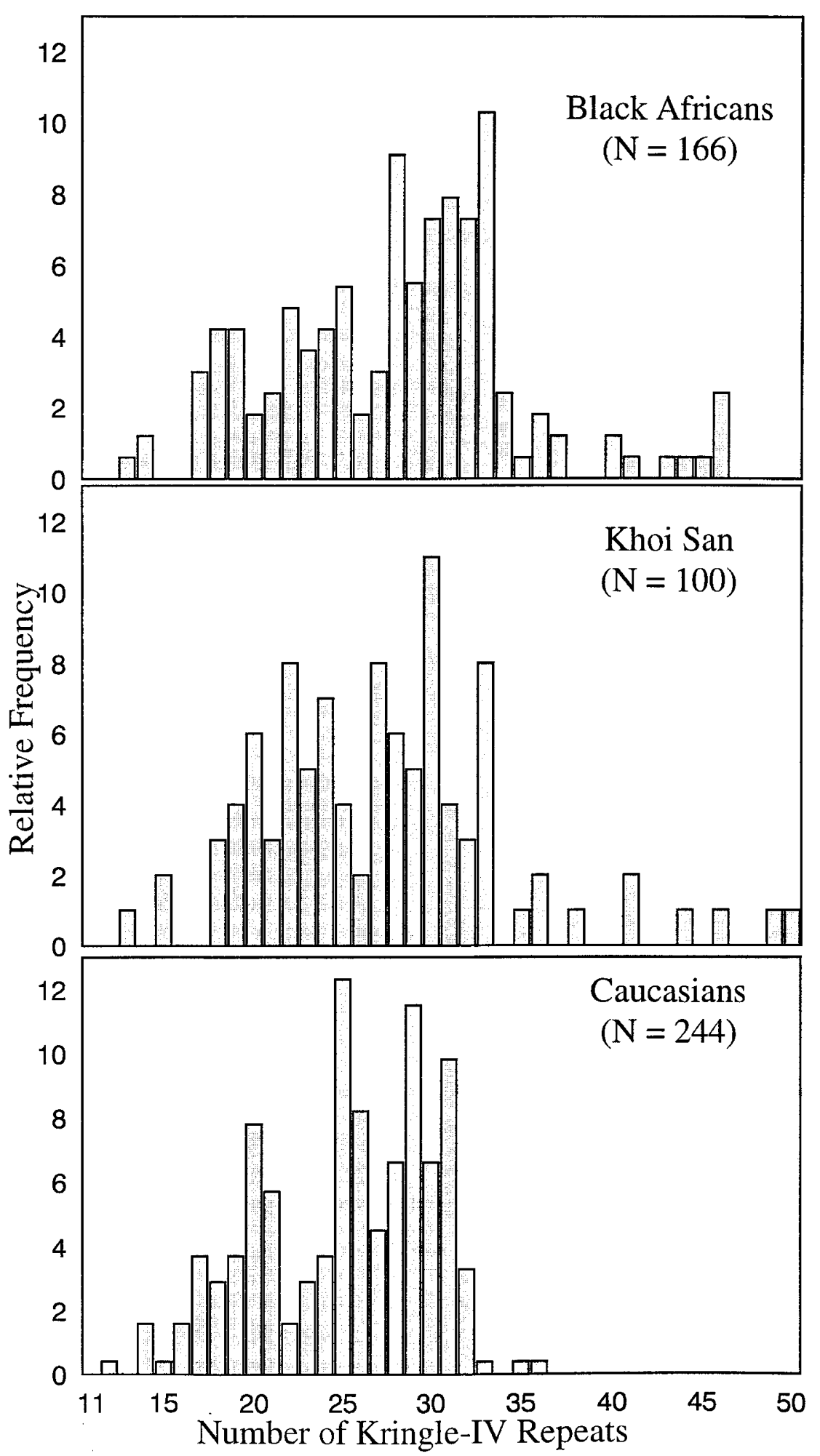

Figure 1 B ar graphs showing the distribution of apo(a) K -IV alleles in the three study populations (only the parents were included). A $\chi^{2}$ analysis shows that the distribution is significantly $(P<0.001)$ different between the three populations. The $A$ frican population samples have higher frequencies of large and very large apo(a) alleles. 
distribution of In $L p(a)$ concentrations was close to normal. The subsequent analysis demonstrated that the transformed data yielded better and more consistent results than untransformed values or square root $L p(a)$ transformed data (not shown). The calculated heritabilities are shown in Table 2. To adjust for differences in the number of children in families we next performed a weighted regression analysis. ${ }^{27}$ The intraclass correlation coefficient $t$ was calculated by random effect A NOVA. Thereby the heritability $\left(h^{2}\right)$ of $L p(a)$ was estimated to be $h^{2}=51 \%$ (SD $12 \%$ ) in the Black South A fricans and $h^{2}=61 \%$ (SD 21\%) in the K hoi San. R esults of the $h^{2}$ analysis are shown in Table 2 .

\section{Heritability of $L p(a)$ Concentrations in Cauca-} sians U sing the same procedures we reanalysed our data set of 63 families from Tyrol (Austria). This resulted in a heritability estimate of $71 \%$ (SD $21 \%$ ) by

Table 1 L p(a) plasma levels in family samples of three populations

\begin{tabular}{lccc}
\hline Population & A ustrians & Blacks & K hoi San \\
\hline Families (n) & 63 & 55 & 22 \\
Individuals (n) & 221 & 216 & 89 \\
Parents & & & \\
age (mean) & 54.9 & 41.5 & 39.7 \\
male/female & $1 / 1$ & $1 / 1$ & $1 / 1$ \\
L p(a) median (mg/dl) & 10.0 & 13.9 & 33.0 \\
IQ D & 28.3 & 17.9 & 31.2 \\
$\quad$ skewness & 1.40 & 4.16 & 0.30 \\
O ffspring & & & \\
age (mean) & 30.7 & 10.7 & 9.4 \\
male/female & $0.98 / 1$ & $1.36 / 1$ & $0.72 / 1$ \\
L p (a) median (mg/dl) & 8.45 & 10.2 & 23.2 \\
IQ D & 22.4 & 12.8 & 36.1 \\
$\quad$ skewness & 1.97 & 2.61 & 0.56 \\
\hline
\end{tabular}

${ }^{\mathrm{a}} \mathrm{QQD}$ inter quartile distance $=$ difference between the 75th and 25th quantile. the weighted analysis of the In transformed $L p(a)$ (Table 2).

\section{Sib Pair Analysis}

For the next analysis we used a variance components model in combination with a quasi-likelihood estimation procedure. ${ }^{28,29}$ This type of analysis was preferred over the classical Haseman-Elston ( $H-E)$ method because of the non-normal distribution of the residuals. A II calculations were based on In $L p(a)$ concentrations. The model allows for the estimation of $\sigma_{a}^{2}$ which is the variance linked to the apo(a) locus, $\sigma_{G}^{2}$ which is the variance contributed by a polygenic component and $\sigma_{\mathrm{E}}^{2}$ which is the residual non-genetic variance. $\left(\sigma_{a}^{2}+\sigma_{\mathrm{G}}^{2}\right) / \sigma_{\mathrm{P}}^{2}$ then defines the total genetic variance as a proportion of the total phenotypic variance as $\sigma_{a}^{2} / \sigma_{p}^{2}$ defines the fraction of explained phenotypic variance due to the apo(a) locus. R esults are presented in Table 3.

Caucasians For our analysis we used different subsets of the A ustrian families which included A) all nuclear families, B) all independent nuclear families to guarantee model assumptions and C) all independent nuclear families with typed parents. In the Black A fricans and K hoi San only one type of these family sets was represented, ie all were independent nuclear families with parents typed for apo(a) alleles. In this case results are considered most reliable since they are not affected by estimates of allele frequencies for the apo(a) locus.

In the Austrian family sample results were very consistent across the different subsets. Independent of the family subset analysed $71 \%$ to $74 \%$ of the total phenotypic variance was explained by variation linked to the apo(a) gene locus. Notably the total genetic variance $\left(\sigma_{a}^{2}+\sigma_{G}^{2}\right)$ and the apo(a) linked genetic variance $\left(\sigma_{a}^{2}\right)$ were identical in the different subsets. Thus there was no evidence for a polygenic component.

Table 2 H eritability of In L p(a) in three populations based on midparent-offspring regression analysis

\begin{tabular}{lcccc}
\hline Population & Austrians & Blacks & K hoi San & pooled Africans \\
\hline $\begin{array}{l}\text { unweighted regression }_{h^{2}} \\
\text { SD }\left(\mathrm{h}^{2}\right)\end{array}$ & 0.65 & 0.65 & 0.52 & 0.73 \\
weighted regression $^{\mathrm{a}}$ & 0.20 & 0.13 & 0.22 & 0.11 \\
$\mathrm{t}$ & & & & \\
$\mathrm{h}^{2}$ & 0.43 & 0.13 & 0.12 & 0.20 \\
SD $\left(\mathrm{h}^{2}\right)$ & 0.71 & 0.51 & 0.61 & 0.65 \\
\hline
\end{tabular}

a weighted regression was performed according to Falconer and $\mathrm{M}$ acK ay, $\mathrm{p} 179^{26}$; t: intraclass correlation coefficient estimated by random effects A N OVA; $h^{2}$ : heritability; SD : standard deviation. 
Rather the residual variability can be due to nongenetic/environmental factors.

The Caucasian sample included three families accounting for almost half of the sib pairs. Repeating the analysis without these families resulted in a lower but not significant estimate (49\%) of the apo(a) linked variance which likely reflects fluctuation due to smaller sample size. The total genetic variance remained almost unchanged $(67 \%)$.

Africans In both A frican samples, the South A frican B lacks and the K hoi San, approximately $64 \%$ (Table 3) of the phenotypic variability in In $L p(a)$ levels was attributable to genetic factors (major gene and/or polygenes). The genetic component however, could not be identified. Though the analysis indicates that 33\% (Blacks) and $34 \%$ (K hoi San) of the phenotypic variability in $L p(a)$ concentrations is explained by variation linked to the major locus apo(a) this is not significant (Table 3). Likewise the polygenic component $\left(\sigma_{G}^{2}\right)$ was not significant. We therefore in a next step pooled the A frican families. B ecause of the differences we had detected between the two populations (Table 1) we introduced 'population' as a covariate into the analysis. A gain the data revealed that a large fraction $(74 \%)$ of the phenotypic variance is explained by genetic factors but the identity of the genetic component remained unclear despite the increased sample size. A lthough the point estimate proposes that about half the genetic variance is explained by the apo(a) locus, these data alone cannot exclude the alternative hypothesis that the apo(a) locus explains all the genetic variance or none of it.

\section{Discussion}

$L p(a)$ levels represent one of the most intriguing quantitative traits in humans the analysis of which has posed several challenges. A s a risk factor for coronary heart disease, peripheral vascular disease, and stroke $L p(a)$ has also attracted much medical attention.

Previous studies have identified the apo(a) gene as a major locus controlling $L p(a)$ plasma concentrations and demonstrated an inverse correlation of transcribed and translated repeats in the apo(a) gene (K IV VNTR) with $L p(a)$ plasma concentrations. This relationship exists in every population studied so far. Molecular biology studies have demonstrated that the effect of the $K$ IV VNTR on L $\mathrm{p}(\mathrm{a})$ levels is direct and causal and exists also in non-human primates. ${ }^{34} \mathrm{H}$ ence this seems to be a basic mechanism underlying the genetic variation in $L p(a)$ concentrations in all human ethnic groups. Despite this similarity there exist also significant differences between human populations. Several studies have documented significantly higher average $L p(a)$ levels in Black populations as compared to Caucasians, ${ }^{20,35-37}$ but the underlying mechanism(s) remained unclear. Differences in the frequency distribution of K IV V NTR alleles certainly do not explain $L p(a)$ level differences among populations. ${ }^{16-18,20} \mathrm{~A} s$ a correlary it has been measured that K IV VNTR allele associated $L p(a)$ concentrations are different in various

Table 3 H eritability of In L p(a) in three populations based on sib pair analysis using a variance component model

\begin{tabular}{|c|c|c|c|c|c|}
\hline Population & Subset & Families/sib-pairs & $\sigma^{2} a / \sigma^{2} p$ & $\left(\sigma_{\mathrm{a}}^{2} / \sigma_{\mathrm{G}}^{2}\right) / \sigma_{\mathrm{P}}^{2}$ & $P$-value $\left(\sigma_{A}^{2}=0\right)$ \\
\hline \multirow[t]{3}{*}{ A ustrians } & $A$ & $63 / 256$ & $74 \%$ & $74 \%$ & $<0.00001$ \\
\hline & B & $51 / 233$ & $\begin{array}{c}73 \% \\
{[36 \% ; 100 \%]}\end{array}$ & $\begin{array}{c}73 \% \\
{[40 \% ; 100 \%]}\end{array}$ & $<0.00001$ \\
\hline & C & $27 / 154$ & $\begin{array}{c}71 \% \\
{[26 \% ; 100 \%]}\end{array}$ & $\begin{array}{c}71 \% \\
{[32 \% ; 100 \%]}\end{array}$ & 0.00031 \\
\hline Blacks & C & $55 / 76$ & $\begin{array}{c}33 \% \\
{[0 \% ; 100 \%]}\end{array}$ & $\begin{array}{c}65 \% \\
{[35 \% ; 95 \%]}\end{array}$ & 0.27345 \\
\hline K hoi San & C & $22 / 31$ & $\begin{array}{c}34 \% \\
{[0 \% ; 100 \%]}\end{array}$ & $\begin{array}{c}63 \% \\
{[0 \% ; 95 \%]}\end{array}$ & 0.27994 \\
\hline pooled A fricans & C & $77 / 107$ & $\begin{array}{c}32 \% \\
{[0 \% ; 97 \%]}\end{array}$ & $\begin{array}{c}74 \% \\
{[39 \% ; 87 \%]}\end{array}$ & 0.11259 \\
\hline
\end{tabular}

$\sigma^{2}$ a: variance of additive genetic component due to major gene (apo(a)); $\sigma_{G}^{2}$ : polygenic variance component; $\sigma^{2}$ P: phenotypic variance; $95 \%$ confidence intervals are given in brackets below the point estimates; D escription of subsets: A : all nuclear families; B: independent nuclear families; $C$ : independent nuclear families with apo(a) genotyping results in parents and children. 
populations. ${ }^{16}$ Further there exist differences in the strength of the negative association between $L p(a)$ levels and KIV repeats across populations and the fraction of the phenotypic variance attributed to the apo(a) size polymorphism in genetic epidemiological studies varies from a low of $28 \%$ in Sudanese to a high of $70 \%$ in Chinese. ${ }^{18}$

This raises the questions whether genetic effects beyond the apo(a) K IV V NTR exist in all populations and if so whether they are the same in different populations. Twin, family and sib pair linkage analysis using genotypic information of the apo(a) locus, which allows estimation of the total genetic contribution to the trait and also specifically the contribution of the apo(a) locus, have only been performed in Caucasians $^{11,12,15}$ and very recently in A frican A mericans. ${ }^{21}$ The present analysis of A frican and Caucasian families has yielded some new insights into the genetic control of $L p(a)$ levels. The most important is that the control of $L p(a)$ concentrations in A fricans and Caucasians appears not to be the same.

The following relevant observations were made:

1) The contribution of genetic factors to $L p(a)$ concentrations is large in all populations (from about $50 \%$ to $70 \%$ );

2) In Caucasians this contribution is considerably less than previously estimated;

3) Whereas variation linked to the apo(a) gene explains virtually all the genetic contribution in Caucasians, this is not the case in A fricans.

These conclusions are based on two types of analysis which gave remarkably consistent results. First, we calculated the heritability of $L p(a)$ levels by a weighted midparent-offspring regression. This resulted in heritabilities of $\mathrm{h}^{2}$ is $71 \%$ for Caucasians, $51 \%$ for Black A fricans, and $61 \%$ for K hoi San. Second, we analysed our data by a variance component model which allowed for the quantification of the total genetic variability, the estimation of additive genetic variability linked to the apo(a) locus $\left(\sigma_{a}^{2}\right)$, and the variability due to polygenes $\left(\sigma_{G}^{2}\right)$ as a fraction of the total phenotypic variability $\left(\sigma_{\mathrm{P}}^{2}\right)$ in $L p(a)$ levels. The proportion of the total phenotypic variability explained by undefined genetic variation was $71 \%$ in Caucasians, $65 \%$ in Blacks and $63 \%$ in $\mathrm{Khoi}$ San. Hence, both estimates of heritability $h^{2}$ and $\left(\sigma_{\mathrm{a}}^{2}+\sigma_{\mathrm{G}}^{2}\right) / \sigma_{\mathrm{p}}^{2}$ gave very similar results in Caucasians and $K$ hoi San and were in an acceptable agreement in Blacks.
Several of our data, some of which are at variance with previous results, need comment. The heritability of $71 \%$ in Caucasians, which according to our analysis is entirely due to the contribution of the apo(a) locus, is lower than in most previous studies which have estimated $h^{2}$ values of $>90 \%$ from twin analysis ${ }^{10,38,39}$ and correlation among sibs. ${ }^{11,12}$ D etermination of $h^{2}$ by correlation analysis of sib data are generally too high and only yield an upper boundary for the estimate of heritability ${ }^{26}$ ( $p 164$ ). Both, shared environment and dominant genetic variance may increase the estimate in such analysis. Thus the $h^{2}$ estimate of $92 \%{ }^{12}$ was probably too high. Twin studies in general also result in an overestimation of heritability ${ }^{26}$ ( $p$ 171). The estimate of $71 \%$ which we have obtained here also appears more realistic than the higher reported values in view of independent lines of evidence. Longitudinal studies suggest that individual variation in $L p(a)$ levels with time is larger than generally considered (unpublished 1998). Furthermore, diet ${ }^{40,41}$ and hormones ${ }^{42-44}$ may have a considerable impact on $L p(a)$ concentrations. We do not, however, ignore that the value of $71 \%$ estimated here is a point estimate with all previous published estimates lying within the range of its $95 \%$ confidence interval. Nevertheless, all previous point estimates were higher. ${ }^{10-12,38,39}$

The contribution of the apo(a) locus to $L p(a)$ level variability in Caucasians is also much less, being about $70 \%$ in the present analysis as opposed to $>90 \%$ in three previous studies. ${ }^{11,12,15} \mathrm{O}$ bviously the contribution to the phenotypic variability in $L p(a)$ levels of the apo(a) locus alone cannot be larger than the total genetic contribution. B oerwinkle et al ${ }^{11}$ have calculated that $>91 \%$ of the variance in $L p(a)$ levels is explained by the apo(a) locus using a weighted $\mathrm{H}$ aseman-E Iston $(H-E)$ method. This method was not appropriate for our data set (see $A \operatorname{mos}^{28}$ ). Sibships with more than five sibs were present in the Tyrolean families. Whereas simulations by $A$ mos et $a^{29}$ demonstrated that up to five sibs per family there is no apparent effect on the $\mathrm{H}-\mathrm{E}$ analysis, data on sibships with $>5$ are lacking. The most serious problem, which may arise if the $\mathrm{H}-\mathrm{E}$ method is applied, is that the distribution of the residuals may significantly deviate from a normal distribution, eg towards a $\chi^{2}$ distribution. For that case A mos et al ${ }^{29}$ demonstrated that the $\mathrm{H}-\mathrm{E}$ estimator is distorted and there exists a considerable loss of power. Therefore we preferred the method proposed by A mos et al. ${ }^{28,29}$ Further, this method has the advantage of introducing covariates and using also the phenotypic 
information of the parents. In addition to the covariate 'population' in the pooled data set we introduced sex and age as independent factors because of the detected differences between the populations. As in previous studies no influence of age and sex was found, and also the estimated heritability did not differ significantly.

We have nevertheless performed an $\mathrm{H}-\mathrm{E}$ analysis of the Tyrolean family sample to compare our results with those of B oerwinkle et al. ${ }^{11} \mathrm{~A}$ ccording to this analysis $80 \%$ of the total phenotypic variability in our sample is explained by variation linked to the apo(a) locus. This value dropped to $66 \%$ when In L p(a) was used.

Together our data indicate that in Caucasians about $70 \%$ of the variability in $L p(a)$ levels is genetically determined and that the genetic component is entirely explained by the major locus apo(a). This should not be misinterpreted to mean that other genes and/or environmental factors may not have a significant impact on $L p(a)$ concentrations in certain subsets of the population. Examples for non-genetic effects are kidney failure ${ }^{45}$ and for genetic effects disorders of lipoprotein metabolism including A betalipoproteinaemia, familial LCAT deficiency, and familial defective apolipoprotein B. ${ }^{46-48}$ The present analysis describes the situation in apparently healthy families/individuals.

We did not obtain unequivocal evidence that the apo(a) gene is a major locus for $L p(a)$ levels in A fricans, unlike Caucasians. This finding is in obvious contrast to the results of $\mathrm{M}$ ooser et $\mathrm{al}^{21}$ who concluded that the apo(a) gene is the major determinant of $L p(a)$ level variation in A frican A mericans. Employing the standard $\mathrm{H}-\mathrm{E}$ method ${ }^{30}$ they detected that $78 \%$ of the variance in their sample are explained by the apo(a) locus. We have reanalysed their data using the variance components model. This did not change the result. Thus the discrepancy between their and our data is not explained by methodological differences. $R$ ather it may have resulted from the different populations analysed. A frican A mericans show admixture of Caucasian and other genes. ${ }^{49,50}$ It should, however, be pointed out that also in the A frican A mericans the contribution of the apo(a) locus to $L p(a)$ level variance was lower $(78 \%)$ than in the respective Caucasian A merican sample ( > $90 \%$ ).

The present analysis alone provides neither definitive data on the type nor the number of genes contributing to the heritability of $L p(a)$ in A fricans. Overall the heritability was lower in Blacks than in Caucasians. Though our present data do not formally exclude the possibility that none of the genetic variance in $L p(a)$ levels in A fricans is explained by the apo(a) locus this is excluded by population genetic studies ${ }^{16,18}$ and cell culture experiments. ${ }^{51} \mathrm{~L}$ arge population studies based on apo(a) genotyping have shown that variation in the number of Kringle IV repeats in the apo(a) gene explains about $38 \%$ of the total phenotypic variance in Blacks and K hoi San. ${ }^{16}$ In the present study $34 \%$ of the phenotypic variance was attributable to the apo(a) locus. This implies that also in A fricans (Blacks, $\mathrm{K}$ hoi San) the K IV VNTR almost entirely explains the contribution of the apo(a) locus to the phenotypic variance in $L p(a)$ levels.

Moreover, this strongly suggests that the residual genetic contribution may be through variation in (an)other gene(s). We find it rather unlikely that the differences between $\mathrm{A}$ fricans and Caucasians identified here are caused by differences in the number, size, and structure of analysed families (see Table 1). Thus other explanations are required. $O$ ne might be the presence of environmental factors in A frican populations as recently proposed. ${ }^{52} \mathrm{~A}$ nother could be the existence of (a) transacting factor(s) in A fricans. This has also been suggested by Mooser et al ${ }^{21}$ for $A$ frican A mericans. It will be a challenge for the future to identify this/those gene(s) which presumably are responsible for the high $L p(a)$ in $A$ fricans. This may give further insight into the genetic regulation of $L p(a)$ concentrations and possibly may provide clues towards the development of drugs with the potential to reduce the concentrations of this risk factor for atherothrombotic disease.

\section{Acknowledgements}

This work was supported by grant P-11695-MED from the Fonds zur Förderung der wissenschaftlichen Forschung in Ö sterreich (A ustrian Science Foundation) to G U. Some of the results of this paper were obtained by using the program package SAGE, which is supported by a US Public Health Service R esource G rant (1 P41 R R 03655) from the N ational Center for $R$ esearch $R$ esources.

\section{References}

1 U termann G: Lipoprotein(a). In: Scriver CR, Beaudet $A$ L, Sly WS, Stanbury JB, Wyngaarden J B, Fredrickson D S (eds). The M etabolic and M olecular B ases of Inherited Disease. McGraw-Hill: New York, 1995, II, pp 1887-1912.

$2 \mathrm{G}$ aw A, H obbs H H: M olecular genetics of lipoprotein (a): new pieces to the puzzle. Curr Opin Lipidol 1994; 5: 149-155. 
3 Sandholzer C, Boerwinkle E, Saha N, Tong MC, U termann G : A polipoprotein(a) phenotypes, $L p(a)$ concentration and plasma lipid levels in relation to coronary heart disease in a Chinese population - evidence for the role of the apo(a) gene in coronary heart disease. J Clin Invest 1992; 89: 1040-1046.

4 Kraft HG, Lingenhel A, K öchl S et al: A polipoprotein(a) kringle IV repeat number predicts risk for coronary heart disease. A rterioscler Thromb Vasc B iol 1996; 16: 713-719.

5 Bostom A G, C upples L A , J enner J L et al: E levated plasma lipoprotein(a) and coronary heart disease in men aged 55 years and younger - a prospective study. JA M A 1996; 276: 544-548.

6 Scanu A M : Lipoprotein(a) - a genetic risk factor for premature coronary heart disease. JAMA 1992; 267: 3326-3329.

7 Sorrentino MJ, Vielhauer C, E isenbart JD, Fless GM, Scanu A M, Feldman T: Plasma lipoprotein(a) protein concentration and coronary artery disease in black patients compared with white patients. A m J M ed 1992; 93: 658-662.

8 Knapp RG, Schreiner PJ, Sutherland SE et al: Serum lipoprotein(A) levels in elderly black and white men in the Charleston Heart Study. Clin Genet 1993; 44: 225-231.

9 MCLean JW, Tomlinson JE, Kuang W et al: CDNA sequence of human apolipoprotein (a) is homologous to plasminogen. Nature 1987; 300: 132-137.

10 A ustin M A, Sandholzer C, Selby JV, N ewman B, K rauss $R M$, U termann $G$ : Lipoprotein(a) in women twins heritability and relationship to apolipoprotein(a) phenotypes. A m J H um G enet 1992; 51: 829-840.

11 B oerwinkle E, Leffert CC, Lin J, Lackner C, Chiesa G, $\mathrm{H}$ obbs $\mathrm{HH}$ : A polipoprotein(a) gene accounts for greater than $90 \%$ of the variation in plasma lipoprotein(a) concentrations. J Clin I nvest 1992; 90: 52-60.

12 K raft H G, K öchl S, Menzel HJ, Sandholzer C, U termann G: The apolipoprotein(a) gene - a transcribed hypervariable locus controlling plasma lipoprotein(a) concentration. Hum G enet 1992; 90: 220-230.

13 Frank SL, K lisak I, Sparkes R S et al: The apolipoprotein (a) gene resides on human chromosome 6q26-27 in close proximity to the homologous gene for plasminogen. $\mathrm{H}$ um G enet 1988; 79: 352-356.

$14 \mathrm{~L}$ indahl G, Gersdorf $\mathrm{E}, \mathrm{M}$ enzel $\mathrm{HJ}$ et al: The gene for the $L p(a)$ specific glycoprotein is closely linked to the gene for plasminogen on chromosome 6. H um G enet 1989; 81: 149-152.

15 D emeester CA, Bu X, Gray RJ, Lusis AJ, Rotter JI: $G$ enetic variation in lipoprotein (a) levels in families enriched for coronary artery disease is determined almost entirely by the apolipoprotein (a) gene locus. A m J H um G enet 1995; 56: 287-293.

$16 \mathrm{~K}$ raft $\mathrm{HG}$, Lingenhel $\mathrm{A}$, Pang RWC et al: Frequency distributions of apolipoprotein(a) kringle IV repeat alleles and their effects on lipoprotein(a) levels in Caucasian, A sian, and A frican populations: The distribution of null alleles is non-random. E ur J H um G enet 1996; 4: 74-87.

$17 \mathrm{G}$ aw $\mathrm{A}$, B oerwinkle $\mathrm{E}$, Cohen J C, Hobbs H H : Comparative analysis of the apo(a) gene, apo(a) glycoprotein, and plasma concentrations of $L p(a)$ in three ethnic groups evidence for no common 'null' allele at the apo(a) locus. J Clin Invest 1994; 93: 2526-2534.
18 Sandholzer C, Hallman D M, Saha N et al: E ffects of the apolipoprotein(a) size polymorphism on the lipoprotein(a) concentration in 7 ethnic groups. H um G enet 1991; 86: 607-614.

19 Trommsdorff $M, K$ öchl S, Lingenhel A et al: A pentanucleotide repeat polymorphism in the $5^{\prime}$ control region of the apolipoprotein(a) gene is associated with lipoprotein(a) plasma concentrations in Caucasians. J Clin I nvest 1995; 96: 150-157.

20 M arcovina SM, A lbers J J, Jacobs D R et al: Lipoprotein[a] concentrations and apolipoprotein[a] phenotypes in $\mathrm{C}$ aucasians and A frican A mericans - The CARDIA Study. A rterioscler Thromb 1993; 13: 1037-1045.

21 M ooser V, Scheer D, M arcovina SM et al: The apo(a) gene is the major determinant of variation in plasma $L p(a)$ levels in A frican A mericans. A m J H um G enet 1997; 61: 402-417.

$22 \mathrm{~K}$ raft $H G$, Windegger $M$, Menzel $H J$, U termann $G$ : Significant impact of the $+93 \mathrm{C} / \mathrm{T}$ polymorphism in the apolipoprotein(a) gene on $L p(a)$ concentrations in A fricans but not in Caucasians: confounding effect of linkage disequilibrium. H um M ol G enet 1998; 7: 257-264.

23 Sandholzer C, Delport R, Vermaak H, U termann G : H igh frequency of the apo epsilon 4 allele in Khoi San from South A frica. H um G enet 1995; 95: 46-48.

24 K ronenberg $F$, L obentanz $E$, K önig $P$, U termann $G$, $D$ ieplinger $\mathrm{H}$ : $\mathrm{E}$ ffect of sample storage on the measurement of lipoprotein(a), apolipoproteins B and A -IV, total and high density lipoprotein cholesterol and triglycerides. J Lipid Res 1994; 35: 1318-1328.

25 Kraft HG, Haibach C, Lingenhel A et al: Sequence polymorphism in kringle IV 37 in linkage disequilibrium with the apolipoprotein (a) size polymorphism. Hum G enet 1995; 95: 275-282.

26 Falconer DS, M acK ay TFC: Introduction to Quantitative G enetics. L ongman: Burnt M ill, 1996.

27 Scheffe $H$ : The A nalysis of Variance. John Wiley: New York, 1959

$28 \mathrm{~A} \operatorname{mos} \mathrm{Cl}$ : Robust variance-components approach for assessing genetic linkage in pedigrees. A m J Hum G enet 1994; 54: 535-543.

29 A mos $\mathrm{Cl}$, Zhu DK, Boerwinkle E: A ssessing genetic linkage and association with robust components of variance approaches. A m J H um G enet 1996; 60: 143-160.

$30 \mathrm{H}$ aseman JK, Elston R C: The investigation of linkage between a quantitative trait and a marker locus. B ehav G enet 1972; 2: 3-19.

31 SAGE Statistical A nalysis for Genetic Epidemiology. 1994. R elease 2.2. Computer program package available from the Department of E pidemiology and Biostatistics, Case Western R eserve U niversity: Cleveland.

32 Young DA, Zerbe GO, Hay WWJ: Fieller's theorem, Scheffe simultaneous confidence intervals and ratios of parameters of linear and nonlinear mixed-effects models. Biometrics 1997; 53: 838-847.

33 Zysow BR, Lindahl GE, Wade DP, K night $B L$, L awn RM : $C / T$ polymorphism in the $5^{\prime}$ untranslated region of the apolipoprotein(a) gene introduces an upstream ATG and reduces in vitro translation. A rterioscler Thromb Vasc Biol 1995; 15: 58-64.

34 White AL, Guerra B, Lanford RE : Influence of allelic variation on apolipoprotein(a) folding in the endoplasmic reticulum. J Biol Chem 1997; 272: 5048-5055. 
$35 \mathrm{H}$ elmhold $M, B$ igge J, $M$ uche $R$ et al: Contribution of the apo(a) phenotype to plasma $L p(a)$ concentrations shows considerable ethnic variation. J Lipid Res 1991; 32: 1919-1928.

36 Parra HJ, Luyeye I, B ouramoue C, Demarquilly C, Fruchart JC: Black-white differences in serum Lp(a) lipoprotein levels. Clin Chim A cta 1987; 168: 27-31.

37 G uyton J R, Dahlen G H, Patsch W, K autz J A , G otto A M J : $R$ elationship of plasma lipoprotein $L p(a)$ levels to race and to apolipoprotein B. Arteriosclerosis 1985; 5(3): 265-272.

38 Hong Y, Dahlen G H, Pedersen N, Heller DA, M cClearn $G E$, de Faire $U$ : Potential environmental effects on adult lipoprotein(a) levels: results from Swedish twins. A therosclerosis 1995; 117: 295-304.

39 Lamon-Fava S, Jimenez D, Christian J C et al: The NH L BI Twin Study: heritability of apolipoprotein A-I, B and concordance for lipoprotein(a). A therosclerosis 1991; 91: 97-106.

40 A ro $A$, Jauhiainen $M$, Partanen $R$, Salminen I, M utanen $M$ : Stearic acid, trans fatty acids, and dairy fat: effects on serum and lipoprotein lipids, apolipoproteins, lipoprotein(a), and lipid transfer proteins in healthy subjects. A m J Clin N utr 1997; 65: 1419-1426.

41 Zock PL, Mensink RP: Dietary trans-fatty acids and serum lipoproteins in humans. C urr O pin L ipidol 1996; 7: 34-37.

42 Tonolo G, Ciccarese M, B rizzi P et al: Cyclical variation of plasma lipids, apolipoproteins, and lipoprotein(a) during menstrual cycle of normal women. A m J Physiol 1995; 269: E 1101-1105.

43 Frazer KA, Narla G, Z hang J L, R ubin E M : The apolipoprotein(a) gene is regulated by sex hormones and acutephase inducers in Y A C transgenic mice. N at G enet 1995; 9: 424-431.
44 H ershkovitz E, L eiberman E, Limony Y, Shany S, Phillip $M$ : Short-term growth hormone therapy increases serum lipoprotein (a) levels in normal short children without growth hormone deficiency. Horm Res 1996; 46: 38-40.

$45 \mathrm{~K}$ ronenberg $\mathrm{F}$, U termann G, D ieplinger $\mathrm{H}$ : L ipoprotein(a) in renal disease. A m J Kidney D is 1996; 27: 1-25.

46 M enzel HJ, D ieplinger $H$, L ackner $K$ et al: A betalipoproteinemia with an A poB-100-lipoprotein(a) glycoprotein complex in plasma - indication for an assembly defect. J Biol Chem 1990; 265: 981-986.

47 Steyrer E, D urovic S, Frank S et al: The role of lecithin: cholesterol acyltransferase for lipoprotein (a) assembly. Structural integrity of low density lipoproteins is a prerequisite for $\mathrm{Lp}(\mathrm{a})$ formation in human plasma. J Clin Invest 1994; 94: 2330-2340.

48 Van der H oek Y Y, Lingenhel A, K raft HG, Defesche JC, $K$ astelein JJP, U termann $G$ : Sib-pair analysis detects elevated $L p(a)$ levels and large variation of $L p(a)$ concentration in subjects with familiar defective A poB. J Clin Invest 1997; 99: 2269-2273.

49 Chakraborty R, Kamboh MI, Nwankwo M, Ferrel RE: Caucasian genes in A merican Blacks: new data. Am J H um G enet 1992; 50: 145-155.

50 Dean M, Stephens JC, Winkler C et al: Polymorphic admixture typing in human ethnic populations. A m J H um G enet 1994; 55: 788-808.

51 Brunner C, L obentanz E M, Pethö-Schramm A et al: The number of identical kringle IV repeats in apolipoprotein(a) affects its processing and secretion by H epG 2 cells. J Biol Chem 1996; 271: 32403-32410.

52 Rotimi CN, Cooper RS, Marcovina SM, McGee D, $O$ woaje $E$, L adipo M : Serum distribution of lipoprotein(a) in A frican A mericans and Nigerians: potential evidence for a genotype-environmental effect. Genet Epidemiol 1997; 14: 157-168. 